DOI: $10.2478 /$ aucft-2013-0016

\title{
INFLUENCE OF DIFFERENT HOUSING SYSTEMS ON THE WELFARE OF CALVES
}

\author{
Václav PÁLKA*1', Miloslav ŠOCH*, Luboš ZÁBRANSKÝ*, Kateřina \\ ŠVEJDOVÁ*, Anna ŠIMKOVÁ*, Zdeněk PEKSA*, Hana DUŠOVÁ* \\ * University of South Bohemia in České Budějovice
}

\begin{abstract}
The aim of this paper was to find out what the system of the technical solution to housing for calf breeding is the most suitable from the point of view of welfare. There were compared four basic types. We focused on the comparison behavior of stabled calves like a lying and eating time. These behavior were observed in all four seasons. At the same time we observed some microclimatic conditions. We focused on the cooling value that refers to the thermal comfort of stabled animals. With a comprehensive examination of all collected and measured values can be recommended to prioritize individual outdoor sheds under shelter and calf house from lightweight steel construction, according to actual economic situation of breeders.
\end{abstract}

Keywords: calves, individual sheds, calf house, behavior, cooling value

\section{INTRODUCTION}

It is important to devote great attention not just to the actual breeding, but the breeding environment of calves. In the Czech Republic most calves are bred at the time of milk nutrition in individual sheds without shelter - VIB, and that is more than three-quarters of all reared calves (Doležal et al., 2008). A smaller part of calves are reared in various types of calf houses, in individual sheds or boxes under shelter or in collective boxes. Rearing calves in VIB, otherwise described as outdoor calf rearing, uses the additive effect of low

${ }^{1}$ Corresponding author. Mailing address: University of South Bohemia in the Czech Budejovice, Faculty of Agriculture, Department of Veterinary Sciences and Product Quality, 370 05, Studentská 13, České Budějovice, Czech Republic, Phone: +420 607577 801, Email: palkav@ seznam.cz

Vol. XVII (2013), no.2 
temperatures of the environment to mobilise the thermoregulatory mechanisms and stimulation of physiological and biochemical processes (Doležal, 2001), the reduction of infection pressure by the prevention of the mutual physical contact of the calves is also significant. The most problematical situation arises above all in high temperatures during the summer season. The top critical temperature for calves is $+25^{\circ} \mathrm{C}$ (Knížková, 2005). The animals most affected are those stabled in individual sheds without shelter. Therefore the etiological signs of animals need to be monitored carefully as one of the most important parameters for considering the welfare. If the calves do well in the environment, they can utilise the nutrients in the feed dose for growth and not to overcome various stress from the environment. On the contrary, calves in an unsuitable environment utilise a great part of the nutrients to compensate for various additional stressors. If kept in an environment with a high temperature thermoregulatory mechanisms are activated that are controlled by a regulatory system containing receptors in the skin, veins, internal organs, hypothalamus and other parts of the brain. The most known reactions to the high temperature are reduction in the intake of feed and transformation of nutrients, restricted movement, search for shade or wind, accelerated breathing, rate of peripheral blood flow and increased perspiration (Mader and Davis, 2004; Illek J. et al., 2007). The reaction of animals also depends on other parameters of the microclimate. Therefore more comprehensive indicators are looked for assessing heat stress. One is the cooling value which considers not just the temperature of the environment but also the flow and relative humidity of air.

\section{MATERIALS AND METHODS}

The aim of this paper is to examine the effect of various types of stabling on calf reared in various macroclimatic seasons of the year. The monitoring focused on the degree of the effect of the type of stabling on the lying and eating time of stabled animals. We made a mutual comparison of all the types of stabling. Calves were included in the monitoring - pied cattle heifers. The experiment was conducted at the ZD Krásná Hora nad Vltavou a.s. farming enterprise specialising in milk production. There were monitored calves in calf houses of a lightweight steel construction (VTL), calf houses of bricks (VTZ), individual sheds without shelter (VIB) and individual sheds under shelter (PIB). Calves were placed in all types of stabling immediately after birth and remained in them until they were removed at the age of 56

Vol. XVII (2013), no.2 
days. The age of the calves during the experiment was about one month. The macroclimatic period was divided into spring, summer, autumn and winter monitoring took place in each season. The feeding and watering technology for all systems was basically the same. During the experiment the feed was given only in the morning at about seven o'clock. Monitoring of the number of lying and eating calves took place in the course of 24 hours in ten-minute intervals. Monitoring could be divided into three time intervals - morning, afternoon and evening. The total number of monitored animals is shown in figure number 1 . In view of the stabling technology it was not possible to use camera systems for monitoring. Two groups of researchers conducted the monitoring. The data were recorded in printed tables. The obtained data were statistically assessed.

Description of the monitored types of stabling:

Calf house of a lightweight steel construction (VTL)

The supporting construction of the calf house is steel and the material of the roof cover is fibre cement with opening up plastic elements. The roof faced on north. The construction of the boxes is metal with wooden panels. There is straw bedding. The area of the box is $3.13 \mathrm{~m}^{2}$.

Calf house of bricks (VTZ)

Boxes are located in the insulated reconstructed brick calf house with a flat soffit. There are continuous holes under the ceiling in the side walls. The construction of the boxes is metal with wooden panels. There is straw bedding. The roof is faced on north-east. The area of the box is $2.70 \mathrm{~m}^{2}$.

Individual sheds without shelter (VIB)

Material: polypropylene; Colour: white; Dimensions in mm (L, W, H): 1810, 1210, 1310; Shed area: $2.19 \mathrm{~m}^{2}$; Run area: approx. $2.5 \mathrm{~m}^{2}$; Ventilation hole in the shed ceiling; There is straw bedding; The entrance is south facing.

Individual sheds under shelter (PIB)

Parameters same like VIB. Shelter: Fibre cement roof on a steel construction. North facing. Roof height $3 \mathrm{~m}$. The shelter meets the purpose of protection against rain, excessive sunlight or gusts of frosty flow of air.

To provide more details about the microclimatic conditions of the environment, throughout the monitoring the average daily cooling value of the outdoor environment and habitation of the animals was measured and the data is found in table number 1 . The so-called "Mannheim Measuring Method" was used which means monitoring times 7, 14, and 21 hours. The values were measured by a Hill catathermometer. Optimal values recommended for cattle range between $170-500 \mathrm{~W} \cdot \mathrm{m}^{-2}$. Values of less than

Vol. XVII (2013), no.2 
$170 \mathrm{~W} . \mathrm{m}^{-2}$ characterise a very hot environment and values above $500 \mathrm{~W} . \mathrm{m}^{-2}$ already represent a feeling of cold.

\section{RESULTS AND DISCUSSIONS}

Table 1 shoes the average daily lying and eating times of animals are expressed in percentages serves as a simple comparison of various types of stabling in various macroclimatic parts of the year.

Table 1. Lying and eating time of one-month-old calves per day (average in \%) and cooling value

\begin{tabular}{|c|c|c|c|c|c|c|c|c|}
\hline & \multicolumn{4}{|c|}{8.2 .2011} & \multicolumn{4}{|c|}{11.5 .2011} \\
\hline & VTL & VTZ & VIB & PIB & VTL & VTZ & VIB & PIB \\
\hline$\varnothing \mathrm{t}$ lying (\%) & 77,36 & 79,12 & 81,95 & 79,59 & 79,46 & 75,44 & 88,15 & 82,35 \\
\hline$\varnothing$ t eating (\%) & 10,89 & 9,52 & 7,95 & 10,58 & 7,42 & 9,09 & 5,30 & 7,23 \\
\hline$\varnothing\left(\mathrm{W} \cdot \mathrm{m}^{-2}\right)$ in & 339 & 346 & 491 & 435 & 122 & 221 & 73 & 103 \\
\hline \multirow[t]{3}{*}{$\varnothing\left(\mathrm{W} \cdot \mathrm{m}^{-2}\right)$ out } & 757 & 786 & 757 & 786 & 238 & 232 & 238 & 232 \\
\hline & \multicolumn{4}{|c|}{ 9.8.2011 } & \multicolumn{4}{|c|}{ 25.10.2011 } \\
\hline & VTL & VTZ & VIB & PIB & VTL & VTZ & VIB & PIB \\
\hline$\varnothing$ t lying (\%) & 77,05 & 76,10 & 85,15 & 79,52 & 77,07 & 81,30 & 83,23 & 79,88 \\
\hline$\varnothing$ t eating (\%) & 8,72 & 8,40 & 6,10 & 8,26 & 10,07 & 9,63 & 7,27 & 8,12 \\
\hline$\varnothing\left(W \cdot m^{-2}\right)$ in & 292 & 336 & 142 & 147 & 316 & 304 & 450 & 417 \\
\hline$\varnothing\left(W \cdot m^{-2}\right)$ out & 340 & 324 & 340 & 324 & 584 & 601 & 584 & 601 \\
\hline
\end{tabular}

Table 1 also shows the average outdoor and indoor cooling value. More detailed information about calf rearing at various parts of the day is found in figure number one where the average lying and eating time of animals during a certain time interval of the day are shown in percentages. Lying time, frequency and duration of lying behaviour has been used as a measure of cattle comfort (Lidfors L. 1989; Brouček J. et al., 2011). The obtained results confirm the notoriously known signs of behaviour of stabled animals and the daily time has a significant effect on the number of eating animals. The lowest numbers were recorded in the night interval, just as stated by (Erina S. et al., 2011) for drinking animals. Likewise the eating time significantly affects the eating time. Obviously in the night interval the lying time of

Vol. XVII (2013), no.2 
animals takes up the greatest time of vital signs. These rules of animal behaviour correspond to their basic physiological needs and the effect of the type of stabling and season on them is minimal. The possibility of movement and age of calves also appears fundamental. Calves spend most of their time lying when very young, but this rest time decreases with age. The lying time in older calves is significantly lower. For example (Acatincai S. et al., 2011) gives only $57.4 \%$ of the day of lying time for three-month-old calves and only $38.5 \%$ for six-month-old calves. On the contrary, the eating time is prolonged (Tripon I. et al., 2011).

In the winter season the longest lying time was recorded for VIB and the shortest for VTL. Overall the lying time in the individual sheds is longer. The longest eating time was recorded for VTL, but the shortest was for VIB. The eating time in the morning and afternoon interval was balanced out for VTZ and VIB. On the contrary, the eating time for VTL was significantly longer in the morning interval and the afternoon interval for PIB. Overall the eating time was shorter in the individual sheds. During the monitoring the average daily temperatures ranged around $7^{\circ} \mathrm{C}$. The hottest environment was in VTL and the coolest was in VIB. Overall the cooling value in the individual sheds was higher and reached the optimum limit of $500 \mathrm{~W} \cdot \mathrm{m}^{-2}$. The lying and eating time corresponded to the high cooling value. The calves tried to reduce the body surface in contact with the cold air and lay down more in the deep bedding. Likewise the eating time became longer so the energy losses for the production of body heat could be compensated which obviously have a negative effect on increment. In the spring season the longest lying time was recorded for VIB and the shortest for VTZ. The daily activity of the calves in the calf houses was very similar in the morning and afternoon interval. In the individual sheds the calves were most active in the morning interval and their activity significantly decreased in the afternoon hours when the highest numbers of lying animals were recorded. Overall the lying time in the individual sheds was longer. The longest eating time was recorded for VTZ, but the shortest was for VIB. The relatively balanced out eating and lying time in the morning and afternoon interval was for VTL, VTZ and even for PIB. On the contrary, the eating time for VIB was significantly shorter in the afternoon interval. Overall the eating time in the individual sheds was shorter. During the monitoring the average daily temperatures ranged around $28^{\circ} \mathrm{C}$. VTZ has the coldest environment and VTB the hottest. Overall the cooling value in the individual sheds was lower and fell below the optimum limit of $170 \mathrm{~W} \cdot \mathrm{m}^{-2}$. The lowest values were

Vol. XVII (2013), no.2 
recorded in VIB in direct sunlight when the indoor microclimate was totally unsuitable. Unfortunately the measured optimal cooling value in VTZ was caused by the dampness of the stable brick. High-pressure cleaning water was used to clean the boxes in the calf houses. This cleaning is unsuitable above all for brick stables with a low ceiling where the dampness gets into the stable construction. The optimal values of the microclimate in VTZ were bought at a high risk of the spread of infection and mould. When comparing data from the farm records, the highest numbers of dead animals were recorded in this type of stabling. The lying and eating time corresponded to the low cooling value. The calves were apathetic and lay down more and looked for shade in the individual sheds. In addition, the eating time was significantly shortened which obviously had a negative effect on increment. The same results were recorded in the summer season when paradoxically the outdoor temperatures were lower. These ranged around $22^{\circ} \mathrm{C}$. In the autumn season the longest lying time was recorded for VIB, but the shortest was for VTL. The greatest daily activity of the calves in the calf houses and in the individual sheds was the same in the afternoon interval when the lowest numbers of lying calves were recorded. Overall the lying time in the individual sheds was longer. The longest eating time was recorded for VTL, but the shortest was for VIB. The relatively balanced eating time in the morning and afternoon interval was in the calf houses. On the contrary, the eating time in the individual sheds was significantly longer in the afternoon interval. Overall the eating time in the individual sheds was shorter. During the monitoring the average daily temperature temperatures ranged around $9^{\circ} \mathrm{C}$. The hottest environment was in VTZ and the coldest in VIB. Better heat conditions in VTZ could have been caused by certain inertia from the summer months thanks to the higher thermal capacity of the walls. Overall the cooling value in the individual sheds was higher. Just as in the winter season it corresponded to the high cooling value of the lying and eating time. The significance of the individual comparisons of various types of stabling is shown in Table 2. Significant differences between individual types of stabling were shown especially in lying time where significance was most often around $\mathrm{p}<0.0001$. Unfortunately such significant differences were not recorded that often at eating time where significance often exceeded $\mathrm{p}>0.05$. The results show that housing and management conditions can affect rest in young ruminants (Arave C. W. et al., 1979; Broom D. M., 1997; Friend T. H., 1989). For VIB the parameters of the internal environment were significantly dependent on sunlight which had a negative effect on animal stabling particularly in the summer months.

Vol. XVII (2013), no.2 
Table 2. Lying and eating time of one-month-old calves in different parts of day (average in \%) and significance of individual comparisons of various types of stabling

\begin{tabular}{|c|c|c|c|c|c|c|}
\hline \multirow{2}{*}{ 8.2.2011 } & \multicolumn{3}{|c|}{ VTL habitation $n=56$} & \multicolumn{3}{|c|}{ VTZ habitation $n=69$} \\
\hline & $4^{00}-12^{00}$ & $12^{00}-20^{00}$ & $20^{00}-4^{00}$ & $4^{00}-12^{00}$ & $12^{00}-20^{00}$ & $20^{00}-4^{00}$ \\
\hline$\emptyset$ t laying (\%) & 67,96 & 72,25 & 92,36 & 73,49 & 75,03 & 89,14 \\
\hline SD & 2,07 & 12,02 & 4,78 & 9,93 & 10,10 & 3,41 \\
\hline$\varnothing$ t eating (\%) & 20,63 & 86 & 2,80 & 1,86 & 2,90 & 4,68 \\
\hline SD & 24 & 6,27 & 1,87 & 31 & 6,71 & 2,58 \\
\hline \multirow{2}{*}{ 8.2.2011 } & \multicolumn{3}{|c|}{ VIB habitation $n=21$} & \multicolumn{3}{|c|}{ PIB habitation $n=29$} \\
\hline & $4^{00}-12^{00}$ & $12^{00}-20^{00}$ & $20^{00}-4^{00}$ & $4^{00}-12^{00}$ & $12^{00}-20^{00}$ & $20^{00}-4^{00}$ \\
\hline$\emptyset$ t laying (\%) & 80,29 & 77,86 & 87,86 & 79,72 & 73,62 & 85,48 \\
\hline SD & 12 & 58 & 3,81 & 40 & 3,95 & 3,82 \\
\hline$\emptyset$ t ea & 48 & 00 & 5,29 & 21 & 5,97 & 6,52 \\
\hline SD & 3,17 & 2,97 & 2,56 & 2,54 & 3,17 & 1,86 \\
\hline \multirow{2}{*}{ 11.5.2011 } & \multicolumn{3}{|c|}{ VTL habitation $n=48$} & \multicolumn{3}{|c|}{ VTZ habitation $n=45$} \\
\hline & $4^{00}-12^{00}$ & $12^{00}-20^{00}$ & $20^{00}-4^{00}$ & $-12^{00}$ & $12^{00}-20^{00}$ & $20^{00}-4^{00}$ \\
\hline$\emptyset$ t laying (\%) & 74,54 & 74,27 & 89,90 & 73,82 & 70,33 & 82,36 \\
\hline SD & 11,16 & 10,16 & 5,96 & 25 & 6,04 & 10,65 \\
\hline$\phi$ t eating $(\%)$ & 10,00 & 8 & 2,13 & 9,07 & 11,76 & 6,38 \\
\hline SD & 7,15 & 8,63 & 1,59 & 3,56 & 3,49 & 3,20 \\
\hline \multirow{2}{*}{ 11.5.2011 } & \multicolumn{3}{|c|}{ VIB habitation $n=20$} & \multicolumn{3}{|c|}{ PIB habitation $n=26$} \\
\hline & $4^{00}-12^{00}$ & $12^{00}-20^{00}$ & $20^{00}-4^{00}$ & $4^{00}-12^{00}$ & $12^{00}-20^{00}$ & $20^{00}-4^{00}$ \\
\hline$\emptyset$ t laying (\%) & 81,95 & 89,15 & 93,60 & 75,81 & 80,62 & 90,92 \\
\hline SD & 0 & & 1,62 & 54 & 43 & 2,03 \\
\hline$\emptyset$ t eating $(\%)$ & 65 & 0 & 2,45 & 73 & 77 & 3,04 \\
\hline SD & 2,95 & 1,20 & 0,99 & 3,45 & 2,00 & 1,15 \\
\hline \multirow{2}{*}{9.8 .2011} & \multicolumn{3}{|c|}{ VTL habitation $n=58$} & \multicolumn{3}{|c|}{ VTZ habitation $n=48$} \\
\hline & $4^{00}-12^{00}$ & $12^{00}-20^{00}$ & $20^{00}-4^{00}$ & $4^{00}-12^{00}$ & $12^{00}-20^{00}$ & $20^{00}-4^{00}$ \\
\hline$\emptyset$ t lay & 68,12 & 75,22 & 88,26 & 65,69 & 79,85 & 83,10 \\
\hline SD & ,70 & & 4,82 & 0,73 & 3,70 & 5,59 \\
\hline$\emptyset$ t eati & 11,33 & 4 & 4,59 & 9,69 & 8,02 & 7,40 \\
\hline SD & 6,12 & 5,23 & 1,92 & 4,88 & 2,21 & 2,71 \\
\hline \multirow{2}{*}{9.8 .2011} & \multicolumn{3}{|c|}{ VIB habitation $n=20$} & \multicolumn{3}{|c|}{ PIB habitation $n=27$} \\
\hline & $4^{00}-12^{00}$ & $12^{00}-20^{00}$ & $20^{00}-4^{00}$ & $-12^{00}$ & $12^{00}-20^{00}$ & $20^{00}-4^{00}$ \\
\hline$\emptyset$ t laying (\%) & 77,85 & 85,00 & 92,85 & 78,52 & 75,93 & 84,15 \\
\hline SD & 4,21 & & 1,59 &, 45 & 3,89 & 2,70 \\
\hline$\emptyset$ t eating $(\%)$ & 8,55 & 0 & 2,75 & 85 & 1,19 & 4,67 \\
\hline SD & 1,97 & 1,47 & 0,87 & 4,48 & 2,82 & 1,23 \\
\hline \multirow{2}{*}{.10.2011 } & \multicolumn{3}{|c|}{ VTL habitation $n=30$} & \multicolumn{3}{|c|}{ VTZ habitation $n=57$} \\
\hline & $1^{00}-12^{00}$ & $12^{00}-20^{00}$ & $20^{00}-4^{00}$ & $4^{00}-12^{00}$ & $12^{00} 20^{00}$ & $20^{00} 4^{00}$ \\
\hline$\emptyset \mathrm{tla}$ & 70,47 & 69,37 & 91,77 & 83,42 & 74,93 & 85,60 \\
\hline SD & 5,82 & & 1,82 & 6,56 & 0,13 & 7,90 \\
\hline$\varnothing$ t ea & 15,50 & 13,13 & 1,27 & 10,11 & 13,49 & 5,19 \\
\hline SD & 3,91 & 5,85 & 0,67 & 4,93 & 6,46 & 2,58 \\
\hline \multirow{2}{*}{10.2011} & & habitation $\mathrm{n}$ & $n=22$ & & habitation $n$ & $n=17$ \\
\hline & $4^{00}-12^{00}$ & $12^{00}-20^{00}$ & $20^{00}-4^{00}$ & $4^{00}-12^{00}$ & $12^{00}-20^{00}$ & $20^{00} 4^{00}$ \\
\hline$\emptyset+$ laying $(\%)$ & 80,32 & 77,55 & 91,95 & 79,00 & 72,41 & 88,35 \\
\hline SD & 4,43 & 6 & 1,59 & 3,23 & 3,43 & 2,86 \\
\hline 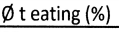 & 8,64 & & 2,82 & 7,59 & 13,00 & 3,65 \\
\hline SD & 2,29 & 2,17 & 1,00 & 2,01 & 1,98 & 1,08 \\
\hline
\end{tabular}

\begin{tabular}{|c|c|c|c|c|c|c|}
\hline \multirow{2}{*}{ 8.2.2011 } & \multicolumn{3}{|c|}{ VTL/VTZ } & \multicolumn{3}{|c|}{$\mathrm{VIB} / \mathrm{PIB}$} \\
\hline & $4^{00}-12^{00}$ & $12^{00}-20^{00}$ & $20^{00}-4^{00}$ & $4^{00}-12^{00}$ & $12^{00}-20^{00}$ & $20^{00}-4^{00}$ \\
\hline laying & $p<0,0001$ & $p<0,0001$ & $p<0,0001$ & $p<0,0001$ & $p<0,0001$ & $p<0,0001$ \\
\hline eating & $p<0,01$ & $p<0,01$ & $p<0,0001$ & $p>0,05$ & $p<0,01$ & $p>0,05$ \\
\hline \multirow[b]{2}{*}{ 8.2.2011 } & \multicolumn{3}{|c|}{$\overline{V T L / V I B}$} & \multicolumn{3}{|c|}{ VTZ/PIB } \\
\hline & $4^{00}-12^{00}$ & $12^{00}-20^{00}$ & $20^{00}-4^{00}$ & $4^{00}-12^{00}$ & $12^{00}-20^{00}$ & $20^{00}-4^{00}$ \\
\hline laying & $p<0,0001$ & $p<0,0001$ & $p<0,0001$ & $p<0,0001$ & $p<0,0001$ & $p<0,0001$ \\
\hline eating & $p<0,0001$ & $p>0,05$ & $p>0,05$ & $p<0,0001$ & $10<0,01$ & $p<0,05$ \\
\hline \multirow{2}{*}{ 8.2.2011 } & \multicolumn{3}{|c|}{$\overline{V T L / P I B}$} & \multicolumn{3}{|c|}{ VTZ/VIB } \\
\hline & $4^{00}-12^{00}$ & $12^{00}-20^{00}$ & $20^{00}-4^{00}$ & $4^{00}-12^{00}$ & $12^{00}-20^{00}$ & $20^{00}-4^{00}$ \\
\hline laying & $p<0,0001$ & $p<0,0001$ & $p<0,0001$ & $p<0,0001$ & $p<0,0001$ & $p<0,0001$ \\
\hline eating & $p<0,0001$ & $p>0,05$ & $p>0,05$ & $p<0,0001$ & $p<0,0001$ & $p<0,01$ \\
\hline \multirow{2}{*}{ 11.5.2011 } & \multicolumn{3}{|c|}{$\overline{V T L / V T Z}$} & \multicolumn{3}{|c|}{ VIB/PIB } \\
\hline & $4^{00}-12^{00}$ & $12^{00}-20^{00}$ & $20^{00}-4^{00}$ & $4^{00}-12^{00}$ & $12^{00}-20^{00}$ & $20^{00}-4^{00}$ \\
\hline laying & $p>0,05$ & $p<0,05$ & $p<0,001$ & $p>0,05$ & $p<0,0001$ & $p<0,0001$ \\
\hline eating & $p>0,05$ & $p>0,05$ & $p<0,001$ & $p>0,05$ & $p<0,01$ & $p>0,05$ \\
\hline \multirow[b]{2}{*}{ 11.5.2011 } & \multicolumn{3}{|c|}{ VIL/VIB } & \multicolumn{3}{|c|}{ VIZ/PIB } \\
\hline & $4^{00}-12^{00}$ & $12^{00}-20^{00}$ & $20^{00}-4^{00}$ & $4^{00}-12^{00}$ & $12^{00}-20^{00}$ & $20^{00}-4^{00}$ \\
\hline laying & $p<0,0001$ & $p<0,0001$ & $p<0,0001$ & $p<0,0001$ & $p<0,0001$ & $p<0,0001$ \\
\hline eating & $p>0,05$ & $p>0,05$ & $p>0,05$ & $p<0,05$ & $p<0,001$ & $p<0,01$ \\
\hline \multirow{2}{*}{ 11.5.2011 } & \multicolumn{3}{|c|}{ VTL/PIB } & \multicolumn{3}{|c|}{$\mathrm{VTZ} / \mathrm{VIB}$} \\
\hline & $4^{00}-12^{00}$ & $12^{00}-20^{00}$ & $20^{00}-4^{00}$ & $4^{00}-12^{00}$ & $12^{00}-20^{00}$ & $20^{00}-4^{00}$ \\
\hline laying & $p<0,0001$ & $p<0,0001$ & $p<0,0001$ & $p<0,0001$ & 1 $p<0,0001$ & $p<0,0001$ \\
\hline eating & $p>0,05$ & $p>0,05$ & $p>0,05$ & $p<0,05$ & $p<0,0001$ & $p<0,01$ \\
\hline \multirow{2}{*}{ 9.8.2011 } & \multicolumn{3}{|c|}{$\overline{V T L / V T Z}$} & \multicolumn{3}{|c|}{ VIB/PIB } \\
\hline & $4^{00}-12^{00}$ & $12^{00}-20^{00}$ & $20^{00}-4^{00}$ & $4^{00}-12^{00}$ & $12^{00}-20^{00}$ & $20^{00}-4^{00}$ \\
\hline laying & $p<0,001$ & $p<0,01$ & $p<0,0001$ & $p<0,001$ & $p<0,01$ & $p<0,0001$ \\
\hline eating & $p>0,05$ & $p<0,05$ & $p>0,05$ & $p>0,05$ & $p<0,05$ & $p<0,05$ \\
\hline & \multicolumn{3}{|c|}{$\overline{V T L / V I B}$} & & $\overline{\mathrm{VTZ} / \mathrm{PIB}}$ & \\
\hline 9.8 .2011 & $4^{00}-12^{00}$ & $12^{00}-20^{00}$ & $20^{00}-4^{00}$ & $4^{n}-12^{n 0}$ & $12^{00}-20^{00}$ & $20^{n 0}-4^{n n}$ \\
\hline laying & $p<0,0001$ & $p<0,0001$ & $p<0,0001$ & $p<0,0001$ & $p<0,0001$ & $p<0,0001$ \\
\hline eating & $p<0,001$ & $p<0,001$ & $p<0,0001$ & $p>0,05$ & $p>0,05$ & $p<0,0001$ \\
\hline & & $\overline{\mathrm{VTL} / \mathrm{PIB}}$ & & & $\overline{V T Z / V I B}$ & \\
\hline 9.8.2011 & $4^{00}-12^{00}$ & $12^{00}-20^{00}$ & $20^{00}-4^{00}$ & $4^{00}-12^{00}$ & $12^{00}-20^{00}$ & $20^{00}-4^{00}$ \\
\hline laying & $p<0,0001$ & $p<0,0001$ & $p<0,0001$ & $p<0,0001$ & $p<0,0001$ & $p<0,0001$ \\
\hline eating & $p<0,01$ & $p<0,01$ & $p<0,001$ & $p<0,05$ & $p<0,0001$ & $p<0,000$ \\
\hline 12 & & VTL/VTZ & & & $\mathrm{VIB} / \mathrm{PIB}$ & \\
\hline 25.10. & $4^{00} 12^{00}$ & $12^{00} 20^{00}$ & $20^{00} 4^{00}$ & $4^{00} 12^{00}$ & $12^{00} 20^{00}$ & $20^{00} 4^{00}$ \\
\hline laying & $p<0,0001$ & $p<0,0001$ & $p<0,0001$ & $p<0,01$ & $p<0,01$ & $p<0,0001$ \\
\hline eating & $>0,05$ & $p<0,01$ & $p<0,0001$ & $p>0,05$ & $p>0,05$ & $p>0,05$ \\
\hline & & VTL/VIB & & & VTZ/PIB & \\
\hline 25.10.2011 & $4^{00}-12^{00}$ & $12^{00}-20^{00}$ & $20^{00}-4^{00}$ & $4^{00}-12^{00}$ & $12^{00}-20^{00}$ & $20^{00}-4^{00}$ \\
\hline laying & $p<0,05$ & $p<0,05$ & $p<0,0001$ & $p<0,0001$ & $p<0,0001$ & $p<0,0001$ \\
\hline eating & $p<0,01$ & $p>0,05$ & $p>0,05$ & $p<0,001$ & $p<0,01$ & $p<0,001$ \\
\hline 25.10 & & $\mathrm{VTI} / \mathrm{PIR}$ & & & $\mathrm{VTZ} / \mathrm{VIB}$ & \\
\hline 2 & $4^{00}-12^{00}$ & $12^{00}-20^{00}$ & $20^{00}-4^{00}$ & $4^{00}-12^{00}$ & $12^{00}-20^{00}$ & $20^{00}-4^{00}$ \\
\hline laying & $p<0,0001$ & $p<0,0001$ & $p<0,0001$ & $p<0,0001$ & $p<0,0001$ & $p<0,0001$ \\
\hline eating & $p<0,01$ & $p>0,05$ & $p>0,05$ & $p<0,001$ & $p<0,001$ & $p<0,0001$ \\
\hline
\end{tabular}

The lying time for VTL, VTZ and PIB was the same. Heat stress of animals stabled in VIB caused a significantly longer lying time but a shorter eating time. The eating time was longer in VTL than in VTZ. The eating time in PIB was significantly longer than in VIB. Above all thanks to VIB the overall lying time in individual sheds was longer than in calf houses but the eating time was shorter in individual sheds. We recorded the most balanced

Vol. XVII (2013), no.2 
lying time in all macroclimatic seasons of the year in VTL. Based on the evaluation of the adequacy of individual types of stabling for calf rearing in terms of analysis, it can be stated that the lying and eating time for VTL, VTZ and PIB was more or less the same in all macroclimatic seasons of the year. The parameters monitored for VIB were negatively affected. There was a higher risk of infectious diseases in VTZ and therefore a higher rate of mortality of calves. Thus of the selected types of stabling we recommend VTL and PIB depending on the economic possibilities of the breeder. The more extensive utilisation of calf houses must also be emphasised which are also used for calves of over 56 days of age.

\section{CONCLUSIONS}

Such general environmental conditions need to be found in which the energy of feed can best be utilised because the level of animal production is directly proportionate to the level of nutrition in the optimal conditions. The main benefit of rearing in sheds is to minimise the possibility of the transmission of disease, of course human labour is demanding. One possibility is the construction of calf houses. The downside here is the spread of disease. A comparison of these types of stabling shows that the following requirements must be keep: Protection against the wind, rain and snow and direct intensive sunlight. An adequate layer of dry and quality straw creates dry bedding. Ensure ventilation in the habitation of calves. Water for calves in the required quality, quantity and temperature. Spacious isolation must enable visual and acoustic contact on the one hand, but prevent mutual physical contact of calves on the other. Observance of a high standard of hygiene of the breeding environment is one of the standard preventive measures for calf rearing. In our specific conditions we did not have such high temperatures as are recorded in other countries, but we did record temperatures above the top limit of the thermal neutral zone. This will obviously be displayed in their growth. Calves have limited possibilities of compensating for heat stress (Šoch M. et al., 1998). The most effective methods of protection against high temperatures are based on evaporation (water evaporation), which are not as yet applied to calves (Brouček J. et al., 2006). To improve calf rearing it would be good to reduce the number of calving dairy cows in the summer season which means limiting cattle mating in September and October.

Vol. XVII (2013), no.2 


\section{ACKNOWLEDGEMENTS}

This work was supported by the grant NAZV QJ1210144 and Grant Agency of the University of South Bohemia GAJU 022/2010/Z. The authors wish to thanks all the farmers from ZD Krásná Hora nad Vltavou a.s.

\section{REFERENCES}

1. Acatincâi, S., Tripon, I., Czister, L. T., Gavojdian, D., Erina, S., Baul, S. \& Râducan, G. G. (2011). Study on Resting Behaviour in Six Months of Age Calves from Romanian Black and White Breed During Summer Season. Scientific Papers: Animal Science and Biotechnologies. 44 (2), $279-281$.

2. Arave, C. W. \& Anderson, M. J. (1979). Feed intake, weight gain, and behavioural activity of heifers on an electronic or tie-up feeding system. Journal of Dairy Science. 62, 1104-1107.

3. Broom, D. M. (1997). Welfare evaluation. Applied Animal Behaviour Science. 54, 21-23.

4. Brouček, J., Kišac, P., Mihina, Š., Hanus, A., Uhrinčat', M., Šoch, M. \& Trávníček, J. (2006). Jsou vysoké teploty škodlivé i pro telata ? Náš chov. 66, 10, 37-40.

5. Brouček, J., Uhrinčat', M. \& Hanus, A. (2011). Maintenance and competitive behaviour study in dairy calves. Slovak Journal of Animal Science. 44, 1, 28-33.

6. Doležal, O. (2001). Odchov telat ve 222 otázkách a odpovědích. Praha. AGROSPOJ, $208 \mathrm{~s}$.

7. Doležal, O., Staněk, S. \& Bečková, I. (2008). Zemědělský poradce ve stáji II. telata. Metodika. Praha Uhříněves. VÚŽV, v.v.i., 63 s.

8. Erina, S., Czister, L. T., Acatincâi, S., Gavojdian, D., Tripon, I., Baul, S. \& Râducan, G. G. (2011). The Influence of Daily Periods on the Drinking Behaviour in Romanian Black and White Primiparous Cows. Scientific Papers: Animal Science and Biotechnologies. 44 (2), 296 298.

9. Friend, T. H. (1989). Recognizing behavioural needs. Applied Animal Behaviour Science. 22, 151-158.

10. Illek, J., Kudrna, V., Matějíček, M., Novák, P. \& Slavík, P. (2007). Heat stress in dairy cows - health, production and reproduction. Náš chov. Praha. 67, 63-65.

Vol. XVII (2013), no.2 
11. Knížková, I. (2005). Chladový a tepelný stres u telat a mladého skotu. In Sborník ze semináře: "Využívání rezerv při intenzivním odchovu telat a jalovic”. 17-21, Praha, ISBN 80-86454-62-2.

12. Lidfors, L. (1989). The use of getting up and lying down movements in the evaluation of cattle environments. Veterinary Research Communications, 13 (4), 307-324.

13. Mader, T.L., Davis M.S. (2004). Effect of management strategies on reducing heat stress of feedlot cattle: Feed and water intake. J. Anim. Sci., 82, 3077-3087.

14. Šoch M., Fišer, A., Novák, P. \& Trávníček, J. (1998). Dynamika výskytu lehkých aeroiontů v teletníku a vzduchu venkovním a jejich vliv na sledované fyziologické hodnoty u telat. Sb. - zoot. řada, České Budějovice, ZF JU. 15, 91-100. ISSN 1210-6240.

15. Tripon, I., Acatincâi, S., Bura, M., Cziszter, L. T., Gavojdian, D., Erina, S., Baul, S. \& Râducan, G. G. (2011). Researches on Feeding Behaviour in Six Months of Age Calves from Romanian Black and White Breed Fed Using Different Feed Space Allowance. Scientific Papers: Animal Science and Biotechnologies. 44 (2), 320 - 324.

Vol. XVII (2013), no.2 